\title{
Destabilizing Haemon: Radically Reading Gender and Authority in Sophocles' Antigone ${ }^{1}$
}

\author{
PETER MILLER
}

As Mark Griffith $(1999,51)$ has remarked, "Gender lies at the root of the problems of Antigone," but much of that attention to gender has focused on analyzing Antigone (e.g., Griffith 2001, Žižek 2004), or the relationship of marriage and consummation in Haemon's violent suicide (Seaford 1987, 120-1; Griffith 1999, 339; Ormand 1999, 79-98). While Haemon's suicide has been understood as a sexual act, scholars have overlooked the inherent ambiguities in this performative action. By connecting Haemon's suicide to Antigone's broader interest in alternative constructions of gender, I read here his multifarious and performative death as an indicator of gender's fluidity and instability; Haemon problematizes the construction of subjectivity, since it is intrinsically linked to gendered identity. Although the play ends conservatively (Griffith 1999, 56-7), readers and audiences are not obliged to accept this conclusion. Rather, Haemon's actions in the play destabilize, at least, the binary and categorical construction of gender and sexuality and the hierarchical and repressive understanding of subjectivity, which remains, even at the tragedy's conclusion, institutionalized. Through an interpretation that emphasizes the multiplicity of performativities and identities that cohere in Haemon, and the reception of his radical identity in the course of the tragedy, an alternative emerges that stresses ambiguity and anti-authoritarianism, instead of descriptivism and tyranny. ${ }^{2}$

Although there is a rich history of criticism that locates a confrontation between oikos and polis in Antigone (e.g., Hegel 1977; cf. SourvinouInwood 1989, 137), or a confirmation of or challenge to kinship models (e.g., Butler 2000, Lacan 2000), my focus is on social identity and the relationship of gender, subjectivity, and authority. By defining Haemon's suicide as a fundamentally ambiguous performative action, I underscore its malleability in the plot of the tragedy, and the ability of audiences both internal (e.g., the Theban dêmos) and external (e.g., the Athenian dêmos, and audiences and readers today) to find, in Haemon's death, a potential escape from the strictures of authority. I begin with an analysis of the agôn between Creon and Haemon (631-780), in which Creon's 
challenge to Haemon's social and gendered identity begins. Having interpreted this interaction in light of Creon's increasingly totalitarian control over the polis, I move to the Messenger's speech, Creon's actions prior to entering the cave (1192-1218), and finally, the interaction between Haemon and Creon in the cave with the suicide itself (1226-43). By situating the confrontation in the cave as a continuation of the prior agôn, I stress how Creon's tyranny has undermined the ability of Haemon to claim a social and gendered identity outside the bounds of his regime. In the conclusion, however, I reread the suicide scene, taking into account the political unrest in Thebes, as well as Judith Butler's critique of Althusser, and the potential radicalism of the subject who refuses ideologically contingent subjectivity (especially Butler 1993, 121-40).

The suicide scene is the culmination of the interaction between Haemon and Creon in Antigone; this interaction, however, begins prior to the Haemon's appearance on the tragic stage. Just before Haemon's entrance, Creon foresees a possible dispute with his son in what, as we shall see, is significant language:

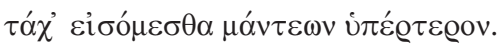

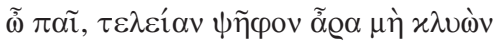

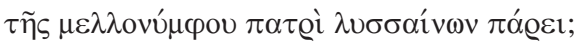

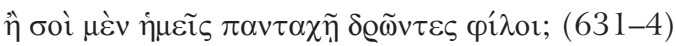

We'll soon know, better than the seers.

My child, having heard the final decree concerning your future bride,

Surely you aren't coming here now, raving mad with your father?

Or, in everything I do, am I dear to you? ${ }^{3}$

After Creon's initial explanation of what makes an ideal child (639-80: constructed, perhaps tellingly, through masculine clichés), Haemon enacts an ultimately futile defense of Antigone. First, he reports the opinions of the Theban population, gathered by eavesdropping from the shadows (i்ò oxótov, 692). While such reports likely represent unrest within the city, the gendered quality of gossip may be relevant (McClure 1999, 56-62), especially given Creon's imminent turn to gender-based insults. ${ }^{4}$ Such insults may hinge on pá $1 \varsigma(700)$ as a dangerous corruption of masculine speech (McClure 1999, 56), and an existential threat to social (and gendered) hierarchy in the polis (McClure 1999, 58). ${ }^{5}$

The most explicit characterization of Haemon occurs in the stichomy- 
thia. Creon's language is extreme and progressively subordinates Haemon: first he is the ally of a woman (740), then beneath a woman (746), and finally slave to a woman (756). Furthermore, Creon's accusation that Haemon is tricking him through wordplay resonates with the gendered nature of gossip, and evokes the traditional association of femininity and verbal persuasion. ${ }^{6} \mathrm{~K} \omega \tau^{\prime} i \lambda \lambda \omega(756)$ is a striking verb, one that Griffith (1999, 251) indicates "usually denotes deceptive, pretty speech (often feminine) that is calculated to disarm, even seduce, an opponent." The systematic devaluing of Haemon through gendered language indicates the relative value which Creon attaches to 'man' and 'woman' as well as the assimilation of his own ideology with a normative role in the construction of gender. ${ }^{7}$

Little ambiguity remains at this point in the exchange. Haemon attempts to use gendered language ironically to rebuke his father (741) and he reacts as we might imagine a son reacting in the face of such vitriol. ${ }^{8}$ In response to Creon's invective, Haemon also turns to emotionally charged speech and by the end of the confrontation he has succumbed to his emotions, abandoned discourse, and stormed off stage: he has seemingly come to grips with the identity imposed upon him, and has foretold his own suicide in ambiguous language (751). ${ }^{9}$ Haemon leaves enraged, an action that probably prompts the Chorus's song to the power of Eros (781-800; Griffith 1999, 255). After his son leaves the stage, Creon manages one further jab, when he advises the Chorus to let Haemon do whatever he wants, even if it is not appropriate for a $\operatorname{man}(768) .{ }^{10}$

In the light of this exchange, let us return to Creon's query at the approach of Haemon. I have referred to this approach as significant. At the literal level, Creon wonders if Haemon will arrive "raving" (633) or whether he will maintain loyalty to his father. ${ }^{11}$ Gender roles come to the fore in the potential alternatives. Passion and madness, while the provenance of young people of both sexes as the Chorus observes (767), are often particular to women, both in their inability to maintain an equilibrium of emotion and in their ritual activities (Zeitlin 1990, 65). ${ }^{12}$ In the context of a series of insults and rhetoric which emphasizes Haemon's subordination to a woman, Creon makes it clear that there is a gendered component to the specific madness he imagines. Indeed, lexical choices also underscore this connection, since a cognate of $\lambda v \sigma \sigma \alpha i v \omega$ has already been used in the play to refer to Ismene, who is uncontrollably emotional (491-2). ${ }^{13}$ Both characters, Haemon and Ismene, either are, or will potentially be, "raving" because of their passion and concern for 
Antigone. For both Creon and Antigone, Ismene represents a stereotypical female: she is disturbed at her sister's proposal to disobey the state (44, 62-4, 78-9), suggests that any action against the state should be done deceptively (84-5), and is concerned with her family, despite Anti-

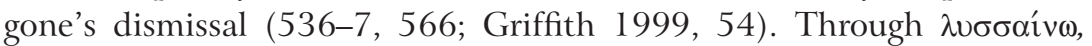
Haemon is analogized to this paradigmatic woman; Creon's emphatic gendered invective thus signals the ideological discourse that envelops Haemon in the course of the agôn.

The two alternatives for Haemon's attitude (and identity), which Creon posits, are not presented equally: $\tilde{\alpha} \varrho \alpha \mu \eta$ anticipates that Haemon will, in fact, not be "raving" on account of Antigone. Creon also frames the address by characterizing his sentence on Antigone as a "final judgment" ( $\tau \varepsilon \lambda \varepsilon i \alpha v ~ \psi \tilde{\eta} \varphi o v, 632$ ); such a description hardly anticipates that he will accept criticism or change his mind. Word choice here is telling: $\psi \tilde{\eta} \varphi \varsigma_{\varsigma}$ was regularly used for voting or a decree carried by votes (LSJ,

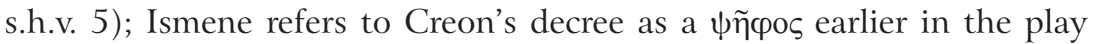

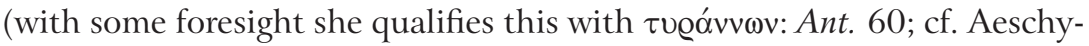
lus, Eum. 680; Euripides, Supp. 484). Thus, the first identity offered Haemon, the one characterized effeminately (and compared through allusion with Ismene), is described as if he arrives in reaction to a democratic decision, as a citizen. In the second alternative, however, the stress is on the inclusion of Haemon in Creon's circle of philoi, that is, an inclusion into his family; as we might expect, the second of the two offered identities has nothing of the effeminizing frame of the first.

In reading Antigone (and broadly, Greek tragedy), Griffith (1999a, 30-5) suggests that there is a disparity between the nature of authority represented on the tragic stage (monarchy) and that realized in the Athenian polis (participatory democracy). According to Griffith (1999a, 68), Athenian political life posited an impossible dialectic of authority in the contrasted roles of son and citizen:

Within a single oikos, the father remains in charge year in and year out, physically, legally, religiously and morally... The democratic principles of rotation of authority, scrutiny of officials before and after their tenure of office, equal votes and freedom of speech, have no place in a well-run patriarchal household.

In the context of home (as son), complete subjection to an unchanging authority (the father) was expected, while in civic life (as citizen), the democratic ethos expected a citizen to both rule and be ruled. In his speech 
after the appearance of Haemon, Creon seems to speak to such an ethos (669), though the sincerity of this speech is undermined by his actions and its military characterization (Griffith 1999, 237). ${ }^{14}$

Haemon embodies the problematic aspects of this dialectic: Is he son or citizen? ${ }^{15}$ Creon's suggested identities seemingly acknowledge these two possibilities as well, since in the first the condemnation of Antigone is framed in a democratic context, while in the second Haemon will be included in his father's philoi, but at the cost of accepting his father's actions "in every respect" (634). Griffith (1999a, 69) offers that part of the dispute between father and son in Antigone can be seen from the perspective of their mutually exclusive concepts of authority: "Creon and Haemon find themselves becoming furiously angry at the outrageous claims of the other, as neither is able to identify or articulate the source of the confusion." That Haemon begins his response to Creon in the guise of son (635), and seemingly acquiesces to his father's authority and assumes the second of two alternatives (to be a philos), may be part of this confusion: Haemon postures as a son but then challenges the authority of his father as a citizen (cf. Ormand 1999, 81).

The four lines preceding Haemon's entry on stage are thus crucial to the subjectivity offered to him by Creon (and authorized by the Chorus of Theban elders), and prefigure the remainder of their interaction. ${ }^{16}$ Polis versus family, alternative sources of authority, and attitudes towards rulership collapse into a binary: loyalty or disloyalty to the father. The structure that Creon adapts to his ideological perspective forces contradictions together and assimilates them with gendered referents: loyalty/ son/subservient/masculine contrasts with disloyalty/citizen/independent/ feminine. The ideological basis for this scheme is readily apparent: masculinity is tied to loyalty (and thus only available to those who are loyal) but also, counterintuitively, to subservience (and thus only available to those who accept Creon's autocracy); conversely, femininity is characterized as disloyal, but independent and active. ${ }^{17}$ In the end, Creon expresses a harsh polarity that condemns dissenters to confused identities; notably, his offered subjectivity, while discordant with the received ideas of normative gender roles, construes a masculinity that suits the current social condition: the autocratic rule of tyrant requires citizens as sons (masculine and subservient). ${ }^{18}$

Haemon leaves the tragic stage (this is his only appearance). He returns to prominence in the tragedy only when Teiresias alludes to his potential death (1064-8), which prompts Creon to finally change his mind (1095-7) and rush off to bury Polynices and free Antigone 
(1108-14). ${ }^{19}$ Only after the Chorus's optimistic hymn to Dionysus does the Messenger return to detail the fate of Creon, Haemon, and Antigone. The Messenger's speech proper begins by recounting the burial of Polynices (1196-1203), and then proceeds to describe Creon's approach to the cave. Just as in the preface to the agôn, Creon attempts to label Haemon's social identity. As the group approaches the tomb, unknown cries are heard from inside (1206-7). While the "someone" ( $\tau 1 \varsigma)$ who hears the cries cannot identify them, and the cries remain ó $\sigma \eta \mu \alpha$ (unintelligible) as they surround Creon (1209), he identifies and interprets the sounds: "My son-his voice greets me" (1214). Not only does he realize an identity (Haemon) for the previously unidentifiable sounds (it is telling that only Creon can give identity to the cries), but he qualifies them too ("son"). ${ }^{20}$ This is rather surprising, considering that at the end of their agôn Creon had dismissed Haemon in the most abusive terms available: "slave to woman," "beneath a woman," etc. ${ }^{21}$ In front of the cave, however, he reasserts his familial bond to his son (one of the identities he offered prior to the agôn) and characterizes Haemon's cries of anguish as greetings. This short address attempts to categorize Haemon as philos, the role offered him earlier, although within the cave in the face of expectorate and at the point of a sword Creon will find that Haemon tries to establish his own hostile identity.

Haemon's attempted patricide has been interpreted variously (122634). Hortmut Erbse, for example, argues that it is motivated by two intertwined angers: Creon's treatment of Antigone and his own inability to protect her (1991, 254; emphasized by the ambiguous meaning of Ant. 1235). ${ }^{22}$ While I find this approach convincing, at least in terms of emotional characterization, the connection between the attack on Creon and the earlier agôn has been overlooked, even though it adds depth to any interpretation of the scene in the cave. Indeed, vocabulary and themes that were prominent in the agôn between Haemon and Creon recur, in particular, in a portion of Creon's long speech in which he advises his son on the appropriate action concerning Antigone:

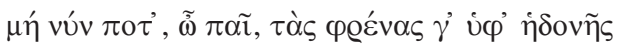

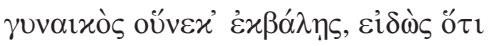

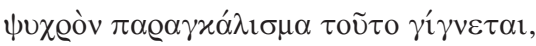

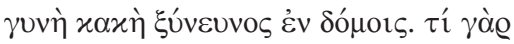

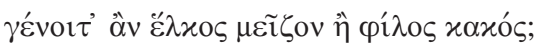

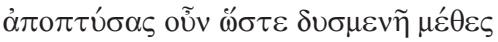

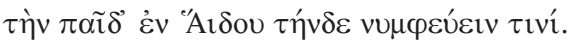


Never, my child, because of pleasure of a woman,

Release your wits; knowing instead that

This pleasure becomes a cold object of your embrace,

A wicked woman as companion in your home.

For what wound would be worse than an evil loved one?

So, spit her out, like an enemy, let that girl

Go and marry someone in Hades.

In the cave scene, ironic recollection of this advice is pervasive. The whole episode is predicated on Haemon's subjection to (potential) pleasure on account of a woman: Antigone is the reason he has gone to the tomb and is found there sobbing over her corpse (1223-5). A cruel twist translates the metaphorical "cold object of your embrace" of Creon's advice into the actual cold, lifeless body of Antigone, which Haemon does, in fact, embrace (1223). More lexical play with Creon's earlier commands establishes the connection. Whereas Creon had told Haemon to metaphorically "spit out" Antigone and leave her to Hades, in the suicide scene Haemon greets his father's exclamatory greeting by actu-

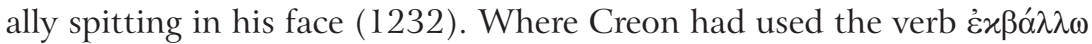
to warn Haemon away from the corrupting influence of Antigone, in the suicide scene this verb is redeployed and inverted, as Haemon's blood "shoots out" onto Antigone's cheek (1238). Creon's belief in the threat of patricide (752) has been translated into Haemon's ineffectual attempted murder of his father (1231-4; cf. Sourvinou-Inwood 1989, 145). Thus, Creon's admonitory and paranoid vocabulary has become the vocabulary of Haemon's erotically charged actions (or, at least, the vocabulary used by the Messenger to report the events), and so the preamble to Haemon's suicide is framed as a continuation of the earlier agôn, and the attempted patricide and suicide should be conceived as a continuation of the themes of that agôn, namely, the ambiguity of Haemon's gendered identity in the authoritarian polis of Creon, passion and madness, and the context of rising popular (and threatening) dissatisfaction. ${ }^{23}$

My interpretation of the suicide as a continuation of the earlier agôn stands in marked contrast to the common view that it represents the consummation of Haemon's marriage to Antigone (Seaford 1987, 1201; Rehm 1994, 65; Griffith 1999, 339). ${ }^{24}$ In fact, the Messenger pro-

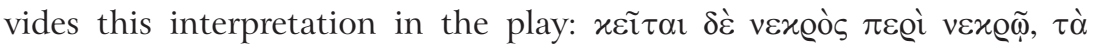

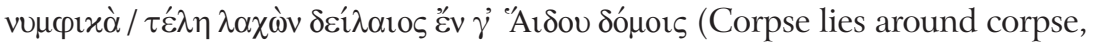
for the wretch seizes his wedding rites in the house of Hades, 1240-1). ${ }^{25}$ 
While the rationale behind the Messenger's interpretation of Haemon's suicide as a consummation seems readily identifiable-the suicide completes the connection between death and marriage that has run through the play (e.g., 806-16) — this explanation should not preclude any ambiguity in the quality of Haemon's actions, especially when we consider, as I do, the suicide scene as a continuation of the earlier confrontation. ${ }^{26}$ Even on a surface reading, the failure of Haemon to embrace Antigone's still hanging corpse, and the feeble description of this action, must attune us, as they assuredly did ancient audiences, to a more complicated characterization. ${ }^{27}$

Elizabeth Craik (2002, 89-90) points out the sexual vocabulary at play in the description of the suicide. The phallic nature of the sword is obvious, and Jeffrey Henderson offers a catalogue of comic doubleentendres that rely on understanding the sword as the male member (e.g., Aristophanes, Lys. 156, 632; Henderson 1991, 120-2). Craik also

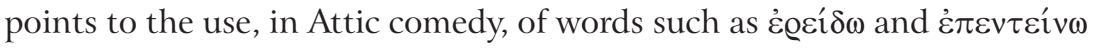
(both of which occur in the suicide scene: 1235-6) as crude sexual euphemisms (Aristophanes, Eccl. 615-6 and Thesm. 488; Craik 2002, 91-2). ${ }^{28}$ She further remarks that didymoi, the standard word for 'testicles,' are evoked in the description of Haemon's sword (1233), and that this might also contribute to an eroticization of the death scene (2002, 92 note 7 ). While she suggests that this vocabulary underlines the Messenger's interpretation $(2002,90)$, I take the vocabulary as part of the underlying sexual and erotic quality of the scene, but without privileging any interpretation; this vocabulary, contra Craik, does not necessarily imply a consummation, or a masculine identity for Haemon. ${ }^{29}$

The erotic quality of the description is complicated by contextualizing the polyvalence of blood; although blood often evokes the battlefield and warfare, indoors it is frequently feminine (and here, of course, the bloodletting takes place in a cave) ${ }^{30}$ In fact, to be the passive agent, the one shedding blood, is, in some texts, typically feminine (Hippocrates, Mul. 1.6.72; Dean-Jones 1991, 101-2). ${ }^{31}$ The name of Haemon, etymologically related to the Greek root for 'bloody' (cf. Chantraine 1968), makes this rather intuitive; ${ }^{32}$ at the same time, the uncertainty of activity or passivity in this etymology enhances the ambiguity of Haemon's relationship to blood. ${ }^{33}$ The identification of activity and passivity with respect to blood as somehow analogous to gendered roles seemed natural to some Greek intellectuals, who considered blood a crucial element to many aspects of biology for a woman. The Hippocratic corpus, for example, makes much of the proper flowing of blood as indicative of the 
healthy working of a woman's body (proper blood loss during menstruation: Hippocrates, Aph. 5.57; lack of menstruation: Hippocrates, Mul. 2.133 and King 1983, 115-7, 124). Blood was also a crucial element in social maturity for a Greek woman. As Helen King $(1983,20)$ puts it, "Becoming a gyne involves a series of bleedings, each of which must take place at the proper time." This series would customarily include menstruation, defloration, and childbirth. ${ }^{34}$ While a paucity of sources makes our ability to reconstruct typical Greek defloration difficult, there is a basis for the claim that in classical times blood was expected to appear at first intercourse (Dean-Jones 1991, 52)..$^{35}$

In light of this cultural, medical, and linguistic context, I suggest that defloration may be an alternative description of the suicide: Haemon penetrates himself and bleeds in a cave, which is described as a wedding chamber, and during what are referred to as wedding rites (1240-1); the erotic allusiveness of Sophocles' vocabulary further underscores the sexual context and provokes the audience's recognition of the eroticization of Haemon's death. The standard reading of this passage, which interprets Haemon's suicide as solely a masculine act, as a metaphorical consummation, ignores both the feminine aspect of being penetrated and the feminine quality of the liquid he emits. ${ }^{36}$ Acknowledging these aspects allows for the possibility that the apparent consummation through ejaculation may simultaneously effect the reverse. Thus, Haemon's suicide is neither 'masculine' nor 'feminine,' but rather emphasizes the multiple identities that can cohere in a single individual, and the impossibility of distinguishing actions into discrete and safely demarcated categories.

Other similar fraught tragic suicides make the ambiguity of Haemon's suicide clearer. A comparative example, which has long been regarded as erotic (Winnington-Ingram 1980, 81; Rehm 1994, 77), is Deianeira in Sophocles' Trachiniae. ${ }^{37}$ Deianeira too kills herself in a bridal chamber (913) and refers to wedding rites (920); she, like Haemon, uses a "doubleedged" sword and stabs herself in the side (930-1). Moreover, her suicide and that of Haemon are both the objects of a narration, even if Deianeira's death is reported by a Nurse rather than a messenger proper. Death by sword is often regarded as a masculine method of suicide, though Deianeira and Haemon problematize this schematization (Loraux $1987,14) .{ }^{38}$ In fact, the eroticization of their suicides combined with their emulation of male death in battle points to an impossibility of setting up such clear distinctions. Victoria Wohl (1998, 35) indicates this when she recognizes Deianeira's death as transgendered: "[She] is both 
a failed man and a failed woman." In contrast, Ajax, the only other male suicide in extant tragedy, is markedly different. While he kills himself with a sword, he does so in full view of the audience and maintains narrative control over the description and timing of his own death (perhaps "self-slaughtered" [Sophocles, Aj. 840-1] has metatheatrical resonance). Also Ajax evokes traditionally masculine concerns about harming enemies (cf. Ant. 641-4), and looks forward hopefully to the treatment of his corpse after death (Aj. 826-30). Moreover, while Deianeira's sword is implicitly characterized as a surrogate for her husband (she kills herself after making Heracles' bed and undressing: Trach. 916, 924-6; Easterling 1982, 190), Ajax's sword contains an epic backstory (Aj. 817) and represents the "completion of Ajax's single combat with Hector" (Hesk 2003, 80). The motives of Deianeira and Haemon are distinct from those of Ajax: whereas their suicides are characterized as acts of madness and passion, Ajax's death restores relationships (Belfiore 2000, 113), mitigates potential shame (Belfiore 2000, 116), and permits him a final "hoplite battle" (Loraux 1987, 20).

The ambiguous nature of Haemon's actions, its "transgendered" character (to borrow Wohl's phrase), and its productive comparison with the equally ambiguous suicide of Deianeira, therefore, indicate the potential to read multiple and simultaneously discordant gender identities. The discordance becomes clearer when the suicide is integrated into the agôn with Creon and the ideological gender roles that are inchoate under his authority. In this culminating scene, Haemon's attempt to act as the active agent in the shedding of blood, a penetrative agent, is an attempt to instantiate a masculine role, a hierarchically powerful one, for himself. He tries to assert his own subjectivity outside the bounds of his father's words and attempts to reestablish the received association of masculinity and activity, which has been perverted and rejected in Creon's Thebes. The failure to kill his own father, as Griffith $(1999,95)$ reminds us, might be interpreted as a failure to proceed to adulthood; Elise Garrison (1999, 114) argues that his suicide may also be the result of his distress at the tyrannical aspirations of his father. The critical disjunction on this issue underscores Griffith's acknowledgement of the contradiction in Attic politics between the unbridled authority of the father and the rotating and temporary power of civic magistrates; that is, Haemon's attempted patricide puts into play the contradictory political dialectic embodied in his person and its analogy to gender, which has already motivated the bitterness of their agôn.

The inability to resolve this contradiction, however, turns back on 
Haemon, as the gendered ramifications of his conflict with Creon since the agôn converge with the political problematic of his identity as citizen and son. In response, Haemon seems to adopt a gender divergent from his biological sex. His actions indicate he has assumed a feminine persona (and 'deflowered' himself), the only identity left available to him in Creon's polarized world of ideologically determined gender (and the gender, in Creon's polarity, connected to citizen status and disloyalty). ${ }^{39}$ Creon, whose speech-acts forcefully regulate Haemon's gender, has been concerned throughout with his ability to dominate and control. His antagonism with Antigone comes, in part, out of her refusal to acknowledge the supremacy of the polis, a power structure that, as the drama unfolds, Creon concentrates in his own person. As a correlative to Antigone's anti-authoritarian stance, Creon disrupts the supposedly essential connection between biological sex and social gender; his binary worldview struggles to accommodate the two radical youths whom he faces. If Antigone is active against the state, in Creon's view, then an essentialist perspective on gender is impossible; in the agôn with Haemon, too, Creon is disturbed by his inability to command his son and by his son's apparent adherence to an alternative power structure, that of the populace (expressed through his report of their misgivings) and Antigone (expressed by his emotional attachment). Again, Creon correlates anti-state action with a divergence from essentialist notions that conflate sex and gender: Haemon becomes feminine because of his allegiance to an alternative power, his posturing as citizen rather than son.

To Creon, whose vision of the world is prefigured by a dichotomous perspective on the possibilities of social identity and who has concentrated into his own person the subject-forming authority of the state, his interpellating address effects his ideology even as it simultaneously subjects his addressee. Creon's authority is not absolute: whether as a father or tyrant, there are potential curbs on his power (the people of Thebes, reports Haemon, are unsettled: 690-9; cf. 505). Nonetheless to Haemon it appears that the dual political and familial authority of Creon renders him, as in Louis Althusser's model, an unassailable authority whose power, despite Haemon's feeble and desperate attempts, cannot truly be challenged. Despite his attempt to establish his own identity, and thus an alternative mode of identity, Haemon fails as echthros. By his assumption of a feminine identity, he subordinates himself to Creon's authority, tacitly acknowledging not only the dominance of Creon politically and the only subjectivity available, but also the structural polarity of Creon's ideology. Even at this moment when Creon has changed course from his 
previously authoritarian ways, Haemon, by continuing his agôn with his father, continues to act under the tyrannical regime. For Creon, any apology, redress, or remonstration is useless in the harsh and ideologically rigid polis he has already established; for Haemon, any escape from that same polis has already been foreclosed.

The perspective that I have outlined here seems rather pessimistic. Haemon's suicide, which might have been interpreted as an act of defiance in the face of Creon's authority, has been reduced to a tacit acknowledgment of the reality of that authority. Two points mitigate this pessimism, however. First, Creon's fate after the suicide, the death of his wife, and his pathetic exit indicate his downfall and the negative consequences of his actions. ${ }^{40}$ Second, and more detrimental to Creon's belief earlier in the tragedy that he had successfully assimilated the power of the body-politic to his own person, is the interpretation of Haemon's suicide that the Messenger offers. While I have argued that Haemon subordinates himself to Creon's authority, the Messenger offers the perspective of the Theban populace, which, Haemon claims in his aborted attempt to defend Antigone, is hostile towards Creon. In fact, we could interpret the Messenger's description of the suicide, in which Haemon is not feminized as Creon wanted but rather implements a typically masculine identity (that is, he metaphorically marries Antigone), as a subversive interpretation: the description is a vision of Haemon's identity that is discordant with the identities offered by Creon. The Messenger's interpretation emphasizes the masculine aspect of Haemon's death by associating him, obliquely, to Iliadic warriors through the semi-erotic description of his body (cf. Vernant 1991). Robert Goheen also recognizes the "structural irony" of this scene, in which Haemon enacts the very words that Creon threatenedto find Antigone a husband in Hades (654; Goheen 1951, 40). The fact that the Messenger frames his description of the scene so as to emphasize this ironic conclusion supports a subversive interpretation. The entirety of the suicide scene exists only as the report of the Messenger, and thus the interpretation at which he arrives-a "marriage in death"-may presuppose his own structuring of the events of the suicide to support that interpretation. When we consider that a report stressing a masculine identity for Haemon stands in stark contrast to the alternatives presented by Creon and to the ideologically based gender identity that is operative in Creon's polis, the Messenger's speech, in its very analysis of the scene, demonstrates a disruptive perspective.

In the context of the Messenger's subversive report, it is instructive to pay close attention to the relatively silent Theban dêmos, whom we might 
imagine, along with the Chorus, as an internal audience to the speech. While critics, even after moving past the idea of the Chorus as "ideal spectator," have regarded it as an entity that models behavior to the audience (Easterling 1997, 164), Antigone puts forward the Theban dêmos as another model audience. ${ }^{41}$ John Gould $(1996,219)$ argues that part of the Chorus's appeal to the audience comes from its enunciation of a "collective response of a group." In commenting on J. Gould's paper, Simon Goldhill $(1996,246-7)$ remarks that the "topography of the Chorus," its social and political roots, play a further role in incentivizing the audience to adopt its perspective. ${ }^{42}$ The Theban populace, despite Griffith's (1999, 56 note 163) assertion that they remain "subdued," indirectly provide a collective response as well: they, like the elders who make up the Chorus, are socially and politically attached to the locale of the action. Felix Budelmann $(2000,203)$ suggests that the Chorus "have no rival for the attention spectators may pay them as a group," and yet in Antigone we explicitly hear the reported dissent of another large group, whose voices, while quiet, are present and indeed potent in the drama (Fletcher 2008, 81). If Sheila Murnaghan (2012, 225) is correct to regard the dramatization of spectatorship as a key feature of Sophocles' technique, then potential spectators and audiences beyond the Chorus must be taken into account. The speech of the Messenger and the misgivings of the population alluded to throughout the play can act as interpretive signposts for an audience receptive to their positionality (contra Griffith 1999, 56 note 163). ${ }^{43}$ Judith Fletcher $(2008,83)$ calls attention to the importance of the dêmos, unseen on stage, for the promulgation of Creon's original kerygma, which is imagined as circulating through "repetition by a public voice"; we might imagine the same process of circulation for the Messenger's report and his interpretation of Haemon's suicide. Creon believes someone has bribed the guards to lie about their culpability in the initial burial of Polynices (290-1; Fletcher 2008, 84), and he regards the act as the work of "perpetrators" (in the plural: 325). By the time Antigone has been indicted, in stark contrast to this early belief in the possibility of mass subversion, Creon has succumbed to his own "fantasy of absolute control" (Fletcher 2008, 85), in which opposition, except in or prompted by the unexpected and impossible Antigone, is hard to believe (cf. 656). ${ }^{44}$ The rumors reported by the skulking Haemon, the propagation of Creon's supposed law, and the ironic and subversive treatment of Haemon's death speak to the potency, despite its subtextual existence, of this alternative collective, another group with whom ancient and modern audiences might identify. 
While Griffith $(1998,741)$ is correct to note that the tragedy ends with a conservative "closing of the aristocratic ranks," the conservatism of tragedy does not prevent any audience from radically interpreting Haemon's actions along with the Messenger. ${ }^{45}$ Haemon, at least momentarily, suggests a different concept of subjectivity, wherein constituent power is not embodied in the authority of the state, the father, or the divine, but in his own actions and words. In her reading of Althusser, Butler critiques the notion of interpellation, arguing that not only does the interpellative hail repress the subject, but it forms a "crucial part of the juridical and social formation of the subject" (1993, 121). In this case, as she suggests, the act of interpellation has a potentially destabilizing effect on the system of ideology and the society that that system supports. By his attack against his father and through his suicide, Haemon resists the eternally ideological subject and embodies the "parodic" and "non-conforming" individual, whom Butler (1993, 122) suggests brings the legitimacy of the system into question. The parody and nonconformity need not be completely realized or successful; rather, the very existence of non-conforming persons and their radical performative possibilities operates as a parody of a system of identification delimited through rigid polarization. ${ }^{46}$

By understanding Haemon's actions in the play in this sense, as a radical example to be exploited and interpreted by the audience, I suggest that even in the face of an ending that emphasizes traditionalism and conservatism, there is room for a radical reading of tragic subjectivity (cf. Wohl 1998, xxiii). Despite the failure of his attempted selfsubjection, Haemon's act constitutes a departure from Creon's totalizing perspective, the collapse of all alternatives and identities into schematized polarities, which handily conform to the ideological needs of an autocratic authority. As I have indicated above, the play presents the audience with a model for such a reading: Haemon reports the misgivings of the population of Thebes towards Creon (a different set of misgivings to those espoused timidly by the Chorus); ${ }^{47}$ furthermore, the Messenger's narrative of the suicide scene emphasizes the role of Haemon in the emasculation (by his flight) of Creon and the collapse of his autocracy. The audience is thus not obliged to accept blindly both the suppression of radicalism and the conservative conclusion. ${ }^{48}$

Helene Foley (1995, 142-3; cf. Goldhill 2009, 46) argues that the play's representation of diverse points of view suggests that the audience might also be expected to divide along similar lines; both Foley (1995, $144)$ and Fletcher $(2008,85)$ compare tragedy to the lawcourts or assem- 
bly as places of debate. Griffith points to the Theater of Dionysus as a "highly-charged, yet securely-demarcated and ritualized, arena for the playing out of social/psychological contestations... in which dangerous and exciting fantasies and identities can safely be confronted and explored" (1998, 36); the audience, however, need not discard these "dangerous fantasies" and "identities" (cf. Zeitlin 1990, 81). Goldhill (2009, 45) highlights the lack of critical attention to the polarity of extremism in Antigone, and the alternatives- "the characters who try to muddle along in a less extremely coloured world"-to the tragedy's extreme main characters. Audience members might find democratic and moderate examples in characters that persist in the face of ideologues, despite the attention and vocalization given to those ideologues in the course of the tragedy. ${ }^{49}$

Regardless of the suppression of radicalism that figures in the dénouement of the play, the example of an alternative reception of radical identity and an alternative to authoritatively granted subjectivity seemingly persists. Haemon's actions and the Messenger's interpretation may point to an opening, since, as Pierre Bourdieu (1991, 127) writes, "Politics begins ... with the denunciation of [the] tacit contract of adherence to the established order which defines the original doxa." In the ambiguities evoked by Haemon's actions and their interpretation, the possibility for a real politics of identity begins in which the body's actions and a participatory collectivity, rather than a hierarchical authority, offers subjectivity. In a lecture inspired by the events in Tahrir Square in 2011 , Butler remarks on the necessity of the body to politics, and the dispossession of the body that any sort of interaction assumes. Since the perspective of others towards one's own body can never be internalized, sociality necessarily means displacement and dispossession of oneself: "My body does not act alone, when it acts politically" (Butler 2011). While Butler goes on to explain how the social quality of bodies operates in the reporting and understanding of public action in the twenty-first century, the connection of an active body, public space, and the inherent inaccessibility of the perceptions of others resonates with the radical example of Haemon. Instead of an identity prefigured by the authoritarian tenets of a tyrant, a father, or a god, there exists in Antigone an opening for a reading (and a reception and interpretation) which not only emphasizes a plurality of models and modes of identity and gender, but also underscores the collective and social process of interaction and identification. While traditional readings of the play highlight the extremism of Creon and Antigone, a radical interpretation remains available that correlates 
divergence with democracy and descriptivism with autocracy, and at the same time leaves open the possibility of a collectivized and participatory notion of persons, identities, and subjects.

\section{Works Cited}

Althusser, L. 2001. Lenin and Philosophy. English translation by B. Brewster. London. Belfiore, E. S. 2000. Murder among Friends: Violation of Philia in Greek Tragedy. Oxford.

Bourdieu, P. 1991. Language and Symbolic Power. English translation by G. Raymond and M. Adamson. Cambridge, MA.

Budelmann, F. 2000. The Language of Sophocles: Communality, Communication and Involvement. Cambridge.

Butler, J. 1988. "Performative Acts and Gender Constitution: An Essay in Phenomenology and Feminist Theory." In S. Case, ed., Performing Feminisms: Feminist Critical Theory and Theatre. Baltimore. 270-82.

1993. Bodies That Matter: On the Discursive Limits of "Sex." New York.

- 1997. The Psychic Life of Power: Themes in Subjection. Stanford.

. 1999. Gender Trouble: Feminism and the Subversion of Identity. New York.

. 2000. Antigone's Claim: Kinship between Life and Death. New York.

- 2011. "Bodies in Alliance and the Politics of the Street." Transversal October. http://eipcp.net/transversal/1011/butler/en (accessed 3 August 2014).

Chantraine, P. 1968. Dictionnaire étymologique de la langue grecque. Paris.

Chou, M. 2012. Greek Tragedy and Contemporary Democracy. New York.

Craik, E. M. 2002. “Significant Language in Sophocles' Antigone 1192-1243.” QUCC 70.1: 89-94.

Davidson, J. 2007. The Greeks and Greek Love: A Radical Reappraisal of Homosexuality in Ancient Greece. London.

Dean-Jones, L. 1991. Women's Bodies in Classical Greek Science. Oxford.

Dover, K. 1989. Greek Homosexuality. Cambridge, MA.

Easterling, P. E. 1982. Sophocles, Trachiniae. Cambridge.

- 1997. "Form and Performance." In P. E. Easterling, ed., The Cambridge Companion to Greek Tragedy. Cambridge. 151-77.

Erbse, H. 1991. "Haemons Liebe zu Antigone." RhM 134: 253-61.

Fletcher, J. 2008. "Citing the Law in Sophocles' Antigone." Mosaic 41.3: 79-96.

Foley, H. P. 1981. "The Conception of Women in Athenian Drama.” In H. P. Foley, ed., Reflections of Women in Antiquity. New York. 127-68.

_. 1995. "Tragedy and Democratic Ideology: The Case of Sophocles' Antigone." In B. Goff, ed., History, Tragedy, Theory: Dialogues on Athenian Drama. Austin. 131-50.

- 2001. Female Acts in Greek Tragedy. Princeton.

Garrison, E. P. 1991. "Attitudes towards Suicide in Ancient Greece." TAPA 1 12: 1-34. . 1995. Groaning Tears: Ethical and Dramatic Aspects of Suicide in Greek Tragedy. Leiden.

Goheen, R. F. 1951. The Imagery of Sophocles' Antigone: A Study of Poetic Language and Structure. Princeton.

Goldhill, S. 1996. “Response to Gould.” In Silk 1996, 244-56. 
2009. "The Audience on Stage: Rhetoric, Emotion, and Judgment in Sophoclean Theatre." In S. Goldhill and E. Hall, eds., Sophocles and the Greek Tragic Tradition. Cambridge. 27-47.

Gould, J. 1980. "Law, Custom and Myth: Aspects of the Social Position of Women in Classical Athens." JHS 100: 3859.

—. 1996. "Tragedy and Collective Experience." In Silk 1996, 217-43.

Gould, T. 1995. “The Unhappy Performative.” In A. Parker and E. K. Sedgwick, eds., Performativity and Performance. New York. 19-44.

Griffith, M. 1999. Sophocles, Antigone. Cambridge.

—. 1999a. "The King and the Eye: The Rule of the Father in Greek Tragedy." PCPS 44: 20-84.

— 2001. "Antigone and Her Sister(s): Embodying Women in Greek Tragedy." In A. Lardinois and L. McClure, eds., Making Silence Speak: Women's Voices in Greek Literature. Princeton. 117-36.

Hame, K. J. 2008. "Female Control of Funeral Rites in Greek Tragedy: Klytaimnestra, Medea, and Antigone." CP 101: 1-15.

Harris, E. M. 2004. "Antigone the Lawyer or the Ambiguities of Nomos." In E. M. Harris and L. Rubenstein, eds., The Law and the Courts in Ancient Greece. London. 19-56.

Hawthorne, K. 2009. “The Chorus as Rhetorical Audience: A Sophoklean AGON Pattern." AJP 130: 25-46.

Hegel, G. W. F. 1977. The Phenomenology of Spirit. English translation by A.V. Miller. Oxford.

Henderson, J. 1991. The Maculate Muse: Obscene Language in Attic Comedy. Oxford.

Hesk, J. 2003. Sophocles, Ajax. London.

Kamerbeek, J. C. 1953. The Plays of Sophocles: Antigone. Leiden.

King, H. 1983. "Bound to Bleed: Artemis and Greek Women." In A. Cameron and A. Kuhrt, eds., Images of Women in Antiquity. London. 109-27.

Knox, B. M. W. 1964. The Heroic Temper: Studies in Sophoclean Tragedy. Berkeley.

Lacan, J. 1988. The Ego in Freud's Theory and in the Technique of Psychoanalysis: Seminar II, 1954-1955. English translation by Sylvana Tomaselli. New York.

- 1992. The Ethics of Psychoanalysis: Seminar VII, 1959-1960. English translation by D. Porter. New York.

Lardinois, A. 2012. "Antigone." In Ormand 2012, 55-68.

Lloyd-Jones, H., and N. G. Wilson. 1990. Sophocles Fabulae. Oxford.

- 1990a. Sophoclea: Studies on the Text of Sophocles. Oxford.

Loraux, N. 1986. "La main d'Antigone." Metis 1: 165-96.

. 1987. Tragic Ways of Killing a Woman. English translation by A. Forster. Cambridge, MA.

McClure, L. 1999. Spoken like a Woman: Speech and Gender in Athenian Drama. Princeton.

Mueller, M. 2011. “The Politics of Gesture in Sophocles' Antigone.” CQ 61: 412-25.

Murnaghan, S. 2012. "Sophocles' Choruses.” In Ormand 2012, 220-35.

Ormand, K. 1999. Exchange and the Maiden: Marriage in Sophoclean Tragedy. Austin.

—. 2003. "Oedipus the Queen: Cross-Gendering without Drag." Theatre Journal 55.1: 1-28.

- ed. 2012. A Companion to Sophocles. Oxford. 
Rehm, R. 1994. Marriage to Death: The Conflation of Wedding and Funeral Rituals in Greek Tragedy. Princeton.

Rosenmeyer, T. G. 1993. "Elusory Voices: Thoughts about the Sophoclean Chorus." In

R. M. Rosen and J. Farrell, eds., Nomodeiktes: Greek Studies in Honor of Martin Ostwald. Ann Arbor. 557-72.

Seaford, R. 1987. “The Tragic Wedding.” JHS 107: 106-30.

Silk, M. S., ed. 1996. Tragedy and the Tragic. Oxford

Sourvinou-Inwood, C. 1989. "Assumptions and the Creation of Meaning: Reading Sophocles' Antigone." JHS 109: 134-48.

Vernant, J. P. 1991. "A 'Beautiful Death' and the Disfigured Corpse in Homeric Epic."

F. Zeitlin, ed., Mortals and Immortals: Collected Essays. Princeton. 50-74.

Winnington-Ingram, R. P. 1980. Sophocles: An Interpretation. Cambridge.

Wohl, V. 1998. Intimate Commerce: Exchange, Gender and Subjectivity in Greek Tragedy. Austin.

Zeitlin, F. 1990. "Playing the Other: Theater, Theatricality, and the Feminine in Greek Drama." In J. J. Winkler and F. Zeitlin, eds., Nothing to Do With Dionysos? Princeton. 130-67.

Žižek, S. 2004. "From Antigone to Joan of Arc." Helios 31.1-2: 51-62.

\section{Notes}

1. I owe a particular debt of gratitude to Christopher G. Brown, Carla C. Manfredi, and A. Suksi for their generosity in reading earlier versions of this article, and for much discussion about Haemon and Antigone. I am grateful to audiences at The University of Western Ontario (2010) and the Classical Association of Canada Annual Meeting (2011) for their insightful questions and comments, which have only helped to improve this paper. I would also like to thank the anonymous reviewer of Helios for her/his incisive and critical suggestions. Any errors or omissions that remain are, needless to say, my own.

2. Butler's theorizing of gender as performative is central to my analysis of Haemon. I draw on her explication (1999, 33 et passim) of the discursive variability of sex and gender and their openness to (re)definition and manipulation. As Butler (1993, 1997) indicates, gender is intimately connected to ideology and subject-formation; in this sense, power and politics are integral to an assessment of Haemon, whose subjectivity is at stake both in the agôn with Creon and in the later suicide scene. Althusser's (2001) influential explanation of the inextricable connections among subjectivity, ideology, and authority, which continues to structure debates on subjectivity (Butler 1997, 106), underlies my analysis of the relationship of Haemon and Creon; I especially view Althusserian ideology through the lens of Butler 1999, which argues for its inherently repressive quality, as well as the potential for resistance in every instance of "interpellation" (1993, 123).

3. Text is that of Lloyd-Jones and Wilson 1990. Unless otherwise noted, all translations are my own.

4. While Creon has already suspected unrest within the city (289-92) and his own home (53l-5), the new report is characterized as particularly partisan to Antigone (e.g., 740). 
5. Many archaic and classical authors characterized women as particularly associated with gossip and chatter. Xenophon, for example, recommends a wife who is so closely supervised that she might ask as few questions as possible; even outside of strict gossip, women's talk is unwanted (Xenophon, Oec. 7.5). In Semonides' fragment on women, gossip is characteristic of the "dog woman" (IEG $\left.{ }^{2} 7.12-5\right)$ as opposed to the silent and praised "bee woman" (IEG $7.90-1)$.

6. Verbal deception is integral to Hesiod's narrative of the creation of Pandora $(O p$. 67-8, 77-8; Theog. 589); $x \omega \tau i \lambda \lambda \omega$ is the word used in the Works and Days (Op. 374) to describe the deceptive woman. Griffith $(1998,26)$ comments on the possibility that Creon fears listening for its inherent connection to a loss of autonomy and servitude.

7. As Knox $(1964,89)$ clarifies, by the agôn with Haemon Creon has assimilated the polis to himself; Rehm $(1994,60)$ agrees that Creon's beliefs necessitate absolute subordination and thus leave no room for dissent.

8. Rehm $(1994,62)$ interprets Haemon's response as a counterfactual, which recognizes the "unrealized connection between men and women that Haemon seems to embody"; for him, Creon should be more like "womanly" Haemon if he is to rule well. Haemon is certainly stressing the need to be flexible, but I am not certain that flexible authority should be correlated with femininity in this scene.

9. On the ambiguity of this warning, see Griffith 1999, 250. With foreknowledge of the end of the play, it is easy to read both meanings into the sentence: Haemon does die, but the events that the death of Antigone precipitates end up figuratively killing Creon (at least, Creon qua autocrat) as well.

10. Creon first threatens that he will kill Antigone in front of Haemon (760-1). This threat is ironically reversed in the end and contributes to my reading of the radical implications of the suicide scene.

11. At this point in the drama, prior to the agôn with Haemon, Creon does not seem to have fully self-identified with the polis; he is, after all, simply stratêgos at the opening of the tragedy (8). In his stichomythia with Antigone, for example, he is still interested in what the Thebans think (508), although he denies Antigone's claim that they are silent in fear of him (510). Throughout the stichomythia with Haemon, however, Creon seems to see himself as an embodiment of the polis; see lines 663-71 (regarding the absolute obedience due to the ruler of a polis), and 736-8 (the backand-forth disagreement on the nature of the state). Following the Haemon episode, Creon's metamorphosis into a tyrant is complete, both thematically and linguistically (see, e.g., 1056).

12. Haemon may embody some of the characteristics of young men to which Aristotle (Rhet. 2.12) draws our attention, although this is only true by the end of his confrontation with Creon. Certainly, Aristotle's characterization of young men as "passionate," "hot-tempered," and unable to "endure being slighted" (Rhet. 2.12.5) does not accord with Haemon in this scene. In contrast, as Erbse (1991, 256) observes, Haemon begins his interaction with Creon dispassionately. The idea that young men are hopeful, somewhat naïve, and courageous may have some resonance (Rhet. 2.12.89), but considering that Creon seems to embody many of the characteristics supposedly confined to youth (e.g., "ambitious of honor" and "desires superiority": Rhet. 2.12.6; cf. Sophocles, Ant. 726-7), Aristotle's judgment here may not have much relevance to our play. Indeed, older men are supposed to qualify all their statements (Rhet. 2.13.1) and desire nothing great (Rhet. 2.13.4); assuredly, Creon, while prone to 
fits of violent outbursts (Rhet. 2.13.13), does not accord with Aristotle's characterization of older men either (as Haemon points out: Ant. 735).

13. Lardinois' (2012, 56-7) observation that Ismene and Haemon were probably played by the same actor may reinforce audience identification of the two characters.

14. Creon's connection to democratic ideology is a vexed issue: Demosthenes approvingly cites part of Creon's opening speech (Ant. 175-90; cf. Demosthenes, 19.247; Sourvinou-Inwood 1989, 139), but fragments of Antiphanes and Eupolis also allude to Haemon's speech, which would seem to indicate divergent evaluations of the democratic credentials of either character (quoted in Foley 1995, 142).

15. I disagree with Sourvinou-Inwood (1998, 145), who argues that the ancient audience would view any confrontation between a father and son negatively. This conclusion ignores Haemon's dual role as citizen and son, as well as the complication this entails for any imagined audience response.

16. Moreover, the public aspect of the address is powerful, as Creon lays claim, in front of (ostensibly) the populace of Thebes, to the power to control identity; as Bourdieu (1991, 121) argues, this claim not only resolves the identity of the individual addressed, but also, through the authoritative structure in which it is conveyed, reifies Creon's very authority.

17. Creon slides between masculinity and femininity in his own understanding of Antigone; at one point he paradoxically declares "this girl is a man" (484-5). His initial suspicions are confined to male subversives (Ormand 1999, 89-90), and when faced with Antigone he is incredulous that a girl could have committed the treasonous act (401-6). Of course he changes his mind later and his comprehension of Antigone's gender and her anti-authoritarian stance are tightly correlated.

18. Creon asserts control by using his literal status as father, the same metaphor at the heart of Lacan's understanding of development and subjectivity, and which is similarly evoked (in the guise of a supreme deity) in Althusser's (2001, 165-70) ideology. Creon has this dual status (familial and political leader) with respect to Haemon, but it is only in their acceptance and acquiescence to his authority that the Chorus grant him this status over the polis as a whole; Creon stands as the enunciator of efficacious interpellations, since he stands in the powerful position of familial and civic authority, embodied in one person.

19. Haemon is mentioned prior to his appearance at Ant. 572 (on the issue of attributing this line, I follow Griffith 1999, 217 and Lloyd-Jones and Wilson 1990a, 127-8, who attribute it to Ismene). Haemon is mentioned in the Messenger's preamble to his speech proper (1175), and finally when Creon bewails his fate and points to Haemon's corpse (likely onstage: 1266).

20. Surely Creon's familiarity, as his father, with Haemon's voice is not the only reason he alone could identify the cries.

21 . While Creon has, at this point, learned from the prophecy of Teiresias that his son's life is in jeopardy (1064-7), the reversal of opinion towards Haemon is still striking. Teiresias has prophesized Haemon's possible death, but the circumstances of this death are entirely unclear; Griffith $(1999,332)$ remarks on the parallelism between Teiresias's prophecy and Creon's deciphering of the events in the cave.

22. Griffith $(1999,65)$ sees this as a failed Oedipal attempt, while Garrison, in contrast, understands the failed patricide as a motivating cause for Haemon's suicide; her psychological approach frames both of Haemon's actions in the tomb as the result 
of grief for his own fate and that of his city (1995, 114). Belfiore (2000, 1 13) conflates Haemon's attempted patricide and the actual suicide, which she regards as indirect patricide.

23. Creon has changed his mind on these issues (1095-7, 1105-6), but to Haemon, who has been away from his father and then in the cave with the corpse of Antigone, the situation in the polis remains as it had been when he confronted his father onstage.

24. All of these critics, despite differing on details, argue for a single gendered reading.

25. The spurt of blood (1238) may reference Aeschylus's Agamemnon 1389-90 (Kamerbeek 1953, 199 and Griffith 1999, 339), where it comes from the mouth of another transgressive character, Clytemnestra.

26. On the marriage to Hades theme, see, among many, Griffith 1999, 236 ad Ant. 653-4 (the first mention of the marriage to Hades theme). The theme is also prominent in Antigone's own lyric lament (806-16).

27. The language of his embrace is difficult to understand and is complicated by textual issues; I follow Griffith 1999, 339. The most reasonable interpretation seems to be that Haemon attempts to grasp Antigone, but his fleeting strength prevents it. This is hardly a masculine seizure of a woman; v̛oós, meaning 'weak' or 'flaccid,' certainly prevents any such reading (cf. Euripides, Phoen. 1439).

28. The word kipos (and synonyms) retains its allusive erotic meaning in later authors as well, e.g., Anth. Pal. 5.237.1, 9.361.5. On grabbing someone "in the middle" as euphemism for sex, whether consensual or forced, see Henderson 1991, 156 and Aristophanes, Ach. 1216.

29. Craik $(2002,93)$ suggests that the blood on Antigone's cheek refers back to the Chorus's ode to Eros (783-4). The association of Eros and a maiden's cheeks is, however, conventional (e.g., Phrynichos, TrGF I F 13); see further, Loraux 1986, 178.

30. On women's suitability to the indoors in classical Athens, see J. Gould 1980, 48.

31. Dean-Jones (1991, 102) points out the correlation of sacrificial animal and woman, which revolves around blood; she also remarks (1991, 101) that Hippocratic medicine analogized menstrual and sacrificial blood. Dover is the classic, though now dated, study of active/passive as defining the roles of Greek sexual activity; see Dover 1989, 16-7 et passim. For an updated, though controversial, analysis of sexual roles in Athens, see Davidson 2007.

32. Loraux (1987, 13) comments on the importance of blood both in the suicide scene and in any understanding of Haemon's name. Rehm $(1994,63)$ concurs and points to the double notion of shared blood and the suicide scene's sharing of blood. Neither considers the potentially ambiguous gendered quality of blood in this scene.

33. Ormand (2003, 9; cf. Wohl 1998, xvii) recognizes Athenian male anxieties as existing on the continuum of activity and passivity representative of masculinity and femininity; Haemon's name and the emission of blood in this scene, seemingly, actualize this anxiety.

34. King (1983, 119) recognizes that the "eternal parthenos" (Artemis) does not shed her own blood during the hunt. She further comments (1983, 119) on the significance of the odd story in Herodotus 4.180, in which Libyan virgins are divided into two groups and fight with stones and sticks; the losers are called pseudoparthenoi, and the distinction between actual and false virgin is based on a being who is unwounded. 
35. Whether classical authors were aware of the hymen is unclear, though a likening of defloration to the breaking of a seal on a wine jug or the breaching of a city's walls implies the metaphor, even without the anatomical information (e.g., the existence of Artemis Lysizonos; see King 1983, 121). Later medical writers argue against the existence of the hymen, but this continues to be a debated issue within the medical corpus; cf. Soranus, Gyn. 1.16-7.

36. Haemon's gender, of course, is also configured by the unusual gender identity of his supposed bride; the bibliography on Antigone and gender is enormous, but useful is Griffith 1999, 52-3. On the contrast between Antigone and Ismene, see Griffith 2001. Antigone's burial of Polyneikes and her activity outside the oikos has been interpreted as masculine and feminine, and has provoked much discussion; see Foley 1981, 179 and 2001, 180; Sourvinou-Inwood 1989, 139-41; Hame 2008. Antigone's hope to gain kleos from her actions (502-4), despite feminine models for kleos (e.g., Penelope, Od. 2.117-28; Alcestis in Euripides, Alc. 938; Foley 1981, 180), is more masculine than feminine, especially considering her goal is to stand up to authority and gain some sort of public recognition (cf. Hawthorne 2009, 36 and Foley 2001, 172-5, which argues that Antigone seems to use the language of the law courts, not the family). Mueller (2011, 413) recognizes a disparity between Antigone's speech and physical habitus. In the latter, she suggests, Antigone is more typically feminine and thus her speech and body reflect her dual gendered nature.

37. Tragic suicide is common (Garrison 1995, 1), but suicide by sword is performed or threatened by only a few characters: Jocasta (Euripides, Phoen. 1455-60) stabs herself in the throat; Eurydice (Ant. 1282-3, 1301-5) may stab her body, though a corrupt text and lacuna make it difficult to be certain (on which see Lloyd-Jones and Wilson 1990a, 148-9). Menoeceus's death (Euripides, Phoen. 91 1-4) should probably be considered an altruistic self-sacrifice rather than a suicide (cf. Garrison 1995, 139 and Belfiore 2000, 107).

38. On the difficulties of the gendered character of Deianeira, see Loraux 1987, 10-4, 50-6; Loraux nonetheless concludes her actions are masculine; Garrison (1996, 63), in contrast, argues for Deianeira's suicide as explicitly feminine. The gender identity crisis faced by Heracles later in the play (Trach. 1062-3, 1075) underscores the polyvalent meaning of suicide and its aftermath; cf. Ormand 2003, 17-8.

39. Butler $(1997,20)$ remarks that abject subjection is likely more desirable than a lack of subjectivity at all; the latter implies no recognizable and enduring social existence.

40. Griffith $(1998,73)$ points to the causal role of Haemon's death (as opposed to that of Antigone or Eurydice) in the downfall of Creon. This interpretation integrates well with the play's conclusion, which from the beginning of the Messenger's speech to its end is concerned with Haemon. Eurydice's death is surely an aspect of the downfall of Creon, but it is precipitated by Haemon's suicide.

41. Goldhill $(2009,27-9)$ indicates the Sophoclean interest in dramatizing the audience. While he analyzes scenes of onstage silent characters (2009, 30-42), nonetheless one might extend this to the unseen, though metaphorically present, Theban dêmos.

42. J. Gould (1996, 236 note 15; Ant. 681, 1093) regards the Chorus of Antigone as marginal because they are explicitly characterized as old men (1996, 236 note 15; Ant. 681, 1093); however, the play highlights their political effectiveness or status on 
several occasions (e.g., 162-9, 806, 842-3, 1098, 1102), and in the course of the tragedy, Creon and Antigone certainly see the Chorus as a group of effective and at least partially authoritative citizens. The restoration of political order at the end of the play seemingly amounts to the reestablishment of an aristocratic oligarchy, in which the Chorus of old men would have a prominent role (Griffith 1999, 56).

43. Sourvinou-Inwood (1989, 146) dismisses Haemon's reporting of the rumored support for Antigone as unsubstantiated and thus impotent (1989, 146), but T. Gould $(1995,41)$ and, to a greater extent, Fletcher $(2008,84)$ signal the importance of the Theban dêmos.

44. On the inherent connection between language and power, especially absolutist fantasies, see Bourdieu 1991, 37-42. Sourvinou-Inwood (1989, 139) sees Antigone's decision to act against the authority of the stratêgos as "illegitimately subversive"; she argues $(1989,142)$ that Creon fears conspiratorial agitators throughout the play, which would activate contemporary Athenian fears of revolution against the politeia of the city. This vision of blind obedience to the speech-acts of magistrates, however, flies in the face of our evidence for Athenian political dissent, not the least of which, the euthyna, was partially responsible for assessing the legality of a magistrate's actions. Fletcher (2008, 82; cf. Harris 2004, 39) furthermore points to the Ephebic Oath, which seems to demand of Athenian citizens a critical position with respect to the law; she regards $(2008,82)$ Antigone's position throughout the play in the context of the euthyna. Harris $(2004,35)$ indicates the problem of the legality of Creon's declarations, since they seem to contradict a central tenet of Athenian legal philosophy that laws are general principles, not orders against specific individuals or at specific times.

45. Griffith $(1998,74)$ explains the seemingly inevitable conclusion of Antigone: "Ugly though the prospect may be of unbridled monarchical rule, it would be even more hideous ... to contemplate a tragic stage, or Greek household ... deprived of its legitimate, paternal authority." My reading of Antigone highlights the play's explicit opening to this divergent "hideous" reading, through both the radical characters and their reception by the Theban populace.

46. Butler (2000, 78 and 82) argues for Antigone as a similar example that forces recognition of the contingency of supposedly essentialist notions of kinship. Antigone's appropriation of the language of authority to challenge the foundation of that authority is a destabilizing act, despite her death (Butler 2000, 5 and 78).

47. The Chorus is characteristically tepid in its response to Creon's authoritarian actions (cf. Rosenmeyer 1993, 561). Antigone claims that despite their silence, the Chorus agree with her position (509). It is unclear whether she is proposing that they stay silent because of fear of Creon, or respect for him (depending on ooí: 509). In any case, Creon seems to think that respect is the cause, since he accuses Antigone of shameless behavior in the following line (510).

48. Griffith $(1999,57)$ imagines that audiences' relationship to the stage action will likely mirror the minor characters; my reevaluation of the Messenger's speech offers a minor character whose position is not part of the conservative 'closing of ranks.'

49. Chou (2012) considers the ancient connection between democracy and tragedy as an important contribution of ancient theater to contemporary democracy. He argues that tragedy's ability to bring otherwise marginalized people and stories onstage $(2012,6)$ speaks to its multivocal potential, and thus its utility as an example for modern democracies. 